\title{
Population structure and reproductive biology of the smalltail shark (Carcharhinus porosus) off Maranhão (Brazil)
}

\author{
Rosangela Lessa $^{\mathrm{AD}}$, Francisco Santana ${ }^{\mathrm{B}}$, Roberto Menni ${ }^{\mathrm{C}}$ \\ and Zafira Almeida ${ }^{\mathrm{A}}$ \\ ${ }^{\mathrm{A}}$ Laboratório de Hidrobiologia - Labohidro/UFMA, Cx. Postal 571, São Luis, MA, Brazil \\ ${ }^{\mathrm{B}}$ Departamento de Pesca/UFRPE, Dois Irmãos, Recife, 52.171-900, PE, Brazil \\ ${ }^{\mathrm{C}}$ Museo de La Plata, Paseo del Bosque s/n, 1900, La Plata, Argentina \\ ${ }^{D}$ Present address: Departamento de Pesca/UFRPE, Dois Irmãos, \\ Recife, 52.171-900, PE, Brazil.email: Lessa@elogica.com.br
}

\begin{abstract}
C. porosus is common throughout the year in shallow waters off the Maranhão coast, northern Brazil, where it is the most abundant elasmobranch species. Of 1128 smalltail sharks collected from June 1984 to November 1987 in gill-nets from coastal waters, $80 \%$ were juveniles. Male and female numbers did not differ from a 1:1 ratio. Modal classes were 50.0-60.0 cm (TL) for both sexes. A $120.5 \mathrm{~cm}$ female was the largest specimen caught and a $29.4 \mathrm{~cm}$ male was the smallest. Age distribution for the whole sample ranged from 0 to $>12$ years. The length-weight relationship did not differ significantly between the sexes. Diameter of ovarian follicles, presence of eggs/embryos and nidamental gland traits in females point to a major physiological change toward maturity at about $70.0 \mathrm{~cm}$. Vitellogenesis was first observed at $63.0 \mathrm{~cm}$, and the smallest of the six pregnant females was $70.0 \mathrm{~cm}$. There was a significant relationship between the number of embryos and female size. From September to November, ovulation and newborns were observed in catches.
\end{abstract}

Resumo. Carcharhinus porosus é comum ao longo do ano em águas rasas do norte do Brasil onde é a espécie mais abundante entre os elasmobrânquios. De 1128 exemplares coletados em águas costeiras de junho 1984 a novembro 1987 em redes de emalhar $\sim 80 \%$ eram jovens. O número de machos e fêmeas não diferiu da razão 1:1. A classe modal foi a de 50.0-60.0 cm para ambos os sexos. Uma fêmea de $120.5 \mathrm{e}$ um macho de $29.4 \mathrm{~cm}$ corresponderam ao maior e ao menor exemplar capturado, respectivamente. A distribuição de idades na amostra total variou de 0 a $>12$ anos. A relação peso-comprimento não mostrou diferenças significativas entre os sexos. O diâmetro dos ovócitos, presença de embriões/ovos e largura da glândula nidamentária nas fêmeas indica aquisição da maturidade em $70.0 \mathrm{~cm}$. Foi estabelecida uma relação significativa entre o número de embriões e o tamanho das femeas. Entre setembro e novembro ocorre a ovulação e recém nascidos foram observados nas capturas.

\section{Introduction}

The smalltail shark, Carcharhinus porosus, a placentally viviparous species, represents $43 \%$ of the total commercial elasmobranch catch off the northern Brazilian coast, between the Tubarão and Lençóis Bays (Lessa 1986). This common inshore tropical shark does not exceed $150.0 \mathrm{~cm}$ total length (TL) in the western Atlantic, where its range extends from the northern part of the Gulf of Mexico $\left(30^{\circ} 30^{\prime} \mathrm{N}\right)$ to southern Brazil (2459’S) (Sadowsky 1967; Compagno 1984). It is caught in shallow waters near the bottom down to $36 \mathrm{~m}$, close to estuaries, by longlines or gill-nets.

Information on $C$. porosus refers to taxonomy (Bigelow and Schroeder 1948; Sadowsky 1967; Garrick 1982; Compagno 1984), male sexual development (Lessa 1986-1987), diet (Lessa and Almeida 1997), and age and growth (Batista and Silva 1995; Lessa and Santana 1998). C. porosus is considered to be the permanently dominant species in the shark community within the study area. Pregnant females, adult males and new-borns have been observed (Lessa and Menni 1994).
Despite being the most abundant elasmobranch in shallow waters, the smalltail shark is a by-catch in different types of fisheries, mainly when small floating gill-nets are used in fisheries directed towards the Serra-Spanish mackerel, Scomberomorus brasiliensis (Collette, Russo and ZavalaCamin, 1978) (Lessa 1986).

A shark collection was conducted from 1984 to 1987 with the aim of supplying information on the general aspects of life cycles required for fishery management. Data analysed here refer to structure, sexual development and reproduction of $C$. porosus in northern Brazil.

\section{Material and methods}

An overall sample, composed of 1128 smalltail sharks, was collected from June 1984 to November 1987, in gill-nets $\sim 900 \mathrm{~m}$ long, $7.5 \mathrm{~m}$ in height with $8.0 \mathrm{~cm}$ stretched mesh, directed to the catch of the Serra-Spanish mackerel. Fisheries operated on the lower part of estuaries, or close to them, between Tubarão Bay and Turiaçú Bay (Fig. 1).

The following data were recorded on each specimen: total length $(\mathrm{cm}$, with tail depressed to be in line with body axis; Compagno 1984), gutted 


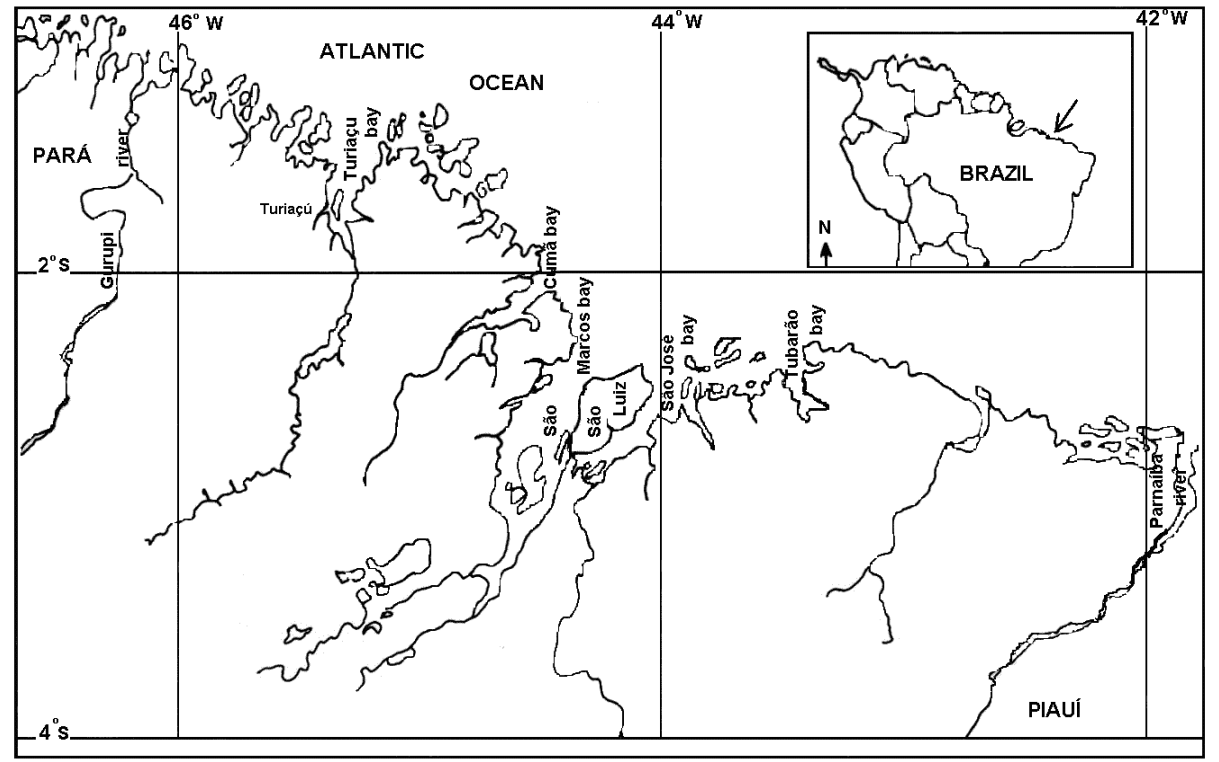

Fig. 1. Site of collection of Carcharhinus porosus off northern Brazil.

weight $(\mathrm{g})$ and liver weight $(\mathrm{g})$ in both sexes; diameter $(\mathrm{cm})$ and colour of major ovarian follicles, uterus contents (eggs/embryos), diameter of nidamental glands $(\mathrm{cm})$ in females and testis weight $(\mathrm{g})$, epididymis width $(\mathrm{cm})$ and clasper length $(\mathrm{cm})$ in males.

The length-weight relationship was calculated by the minimum-squaresfitting method to estimate $a$ and $b$ parameters of the function $[\mathrm{GW}]=a[\mathrm{TL}] b$, where $\mathrm{GW}$ is the gutted weight. Differences between regressions derived for each sex were tested by analyses of covariance, ANCOVA (Zar 1984).

Males were considered to be mature at $71.0 \mathrm{~cm}$ according to Lessa (1986-1987), whereas inferences on female maturity were based on nidamental gland width $>1.0 \mathrm{~cm}$, presence of vitellogenic follicles in ovaries and the presence of eggs or embryos in the uterus.

Seasonal aspects of reproduction, across quarterly periods (JanuaryMarch, April-June and so forth) were evaluated in 105 specimens (58 males and 47 females) larger than $70.0 \mathrm{~cm}$ with regard to variation in several organs of each sex, including weight of gonads, liver, claspers size, ovarian follicles and embryo size. Kruskal-Wallis tests were performed to test differences between distributions (Siegel 1981).

A relationship between the number of embryos/eggs and female sizes was derived by regrouping data from Stride et al. (1992) to the present data.

The relative age composition of samples was obtained from the inverse von Bertalanffy equation (Sparre and Venema 1997). Thus, $\left[\mathrm{TL}_{i}\right]=t_{0}-1 / k \ln \left(1-L_{t} / L_{\infty}\right)$ where $\mathrm{TL}_{i}$ is the predicted age at length $i, t_{0}$ is the von Bertalanffy theoretical age at which length is zero, $k$ is the von Bertalanffy constant, $L_{t}$ is the mean size and $L_{\infty}$ is the mean asymptotic length. The von Bertalanffy parameters employed for the age-structure analysis were $L_{\infty} 136.4 \mathrm{~cm}, k 0.77$ year $^{-1}$ and $t_{0}-3.27$ years (Lessa and Santana 1998).

Differences in frequency data between sexes were tested by $\chi^{2}$ with Yate's correction (Browner and Zar 1984). In all statistical analysis a significance level of $P<0.05$ was required for rejection of the null hypothesis (Zar 1984). Throughout this study, length always refers to total length.

\section{Results}

\section{Length, age and sex composition}

In all, 544 males and 584 females were collected with a male:female ratio of $0.93: 1$, not significantly differing from the $1: 1$ ratio $(P>0.05)$. For 965 specimens caught in $1984-85$,
1985-86 and 1986-87, those smaller than the size for the onset of maturity $(70.0 \mathrm{~cm}$ for females, $71.0 \mathrm{~cm}$ for males) corresponded to $88.0 \%, 83.4 \%$ and $70.9 \%$ (females) and $86.9 \%$, $93.3 \%$ and $60.2 \%$ (males) in the three years (Fig. 2); differences among years in size distributions were significant for males (Kruskal-Wallis, $P<0.05)$ but not for females $(P>0.05)$.

In most monthly samples, one or the other sex dominated, without any clear trend. The largest specimen was a $120.5 \mathrm{~cm}$ female caught in September 1984, and the smallest was a $29.4 \mathrm{~cm}$ male with a fresh umbilical scar, caught in October 1984. Most samples displayed modal classes in 50.0 to 60.0 $\mathrm{cm}$ for both sexes.

Considering the three successive years, $\sim 78 \%$ of females and $\sim 82 \%$ of males were less than 6 years old. Neonate males were caught in 1984-85 and 1985-86 and neonate females in all three years, corresponding to fish from $30.0 \mathrm{~cm}$ (birth length) to $35 \mathrm{~cm}$, a weight range of $150-235 \mathrm{~g}$.

In the overall sample the largest individual for which vertebrae were examined measured $101.0 \mathrm{~cm}$ and was 12 years old. Thus, specimens larger than $101.0 \mathrm{~cm}$ were considered to be 12 years old or older, and age in the whole sample ranged from 0 (newborns) to more than 12 years with modal ages of 2, 3 and 2 years for 1984-85, 1985-86 and 1986-87, respectively (Fig. 2).

Length-weight (gutted) relationships derived for each sex separately did not differ (ANCOVA, $P>0.05$ ) and a single equation was therefore calculated for both sexes (Fig 3).

\section{Sexual development}

The size at maturity for males was confirmed as $71.0 \mathrm{~cm}$, with $75.0 \mathrm{~cm}$ as the size at which $100 \%$ of individuals were mature. 

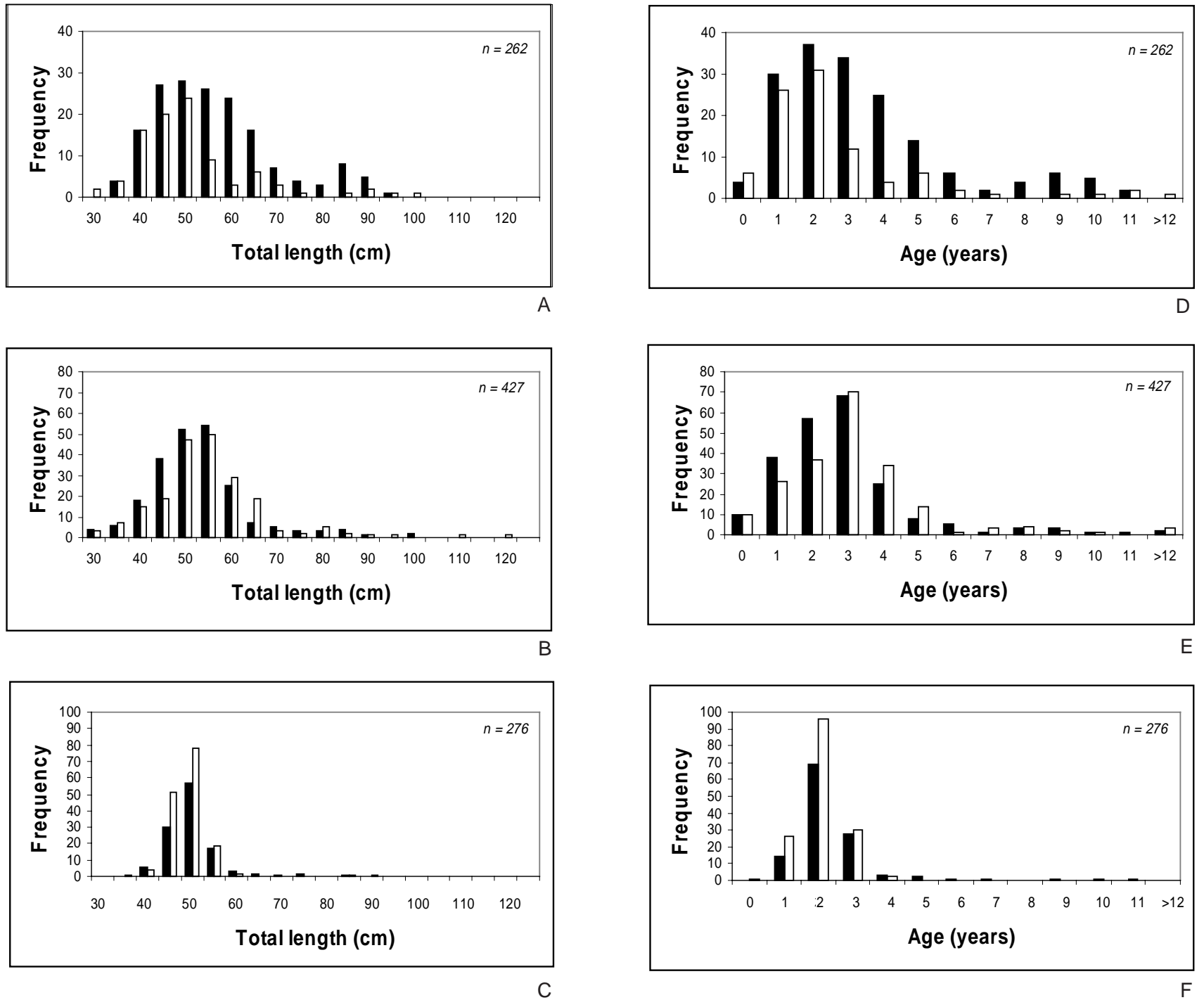

Fig. 2. Length and age distributions of Carcharhinus porosus off northern Brazil: $(A, D)$ July 1984 to June 1985 ; (B,E) July 1985 to June 1986 ; (C,F) July 1986 to June 1987 . White columns, females; black columns, males. Note different values in ordinates for $A-D, B-E$ and $C-F$.

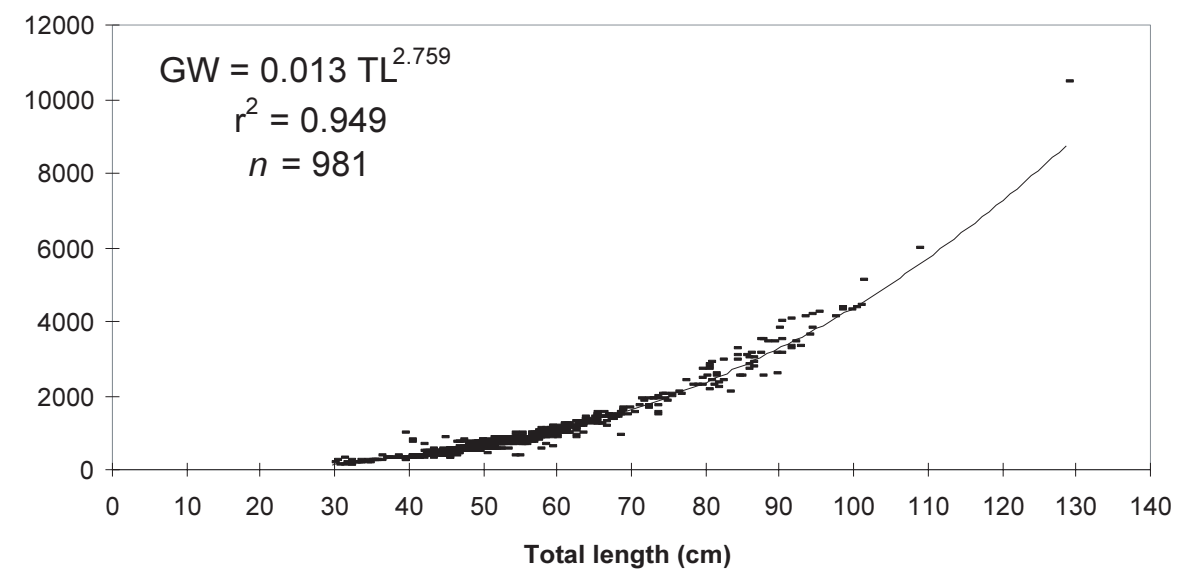

Fig. 3. Relationship between total length (TL) and gutted weight (GW) (both sexes) for Carcharhinus porosus from northern Brazil. 
In females, ovary weight increased with total length of fish (Fig. 4A). Specimens from birth at around $30.0 \mathrm{~cm}$ to juveniles at about $70.0 \mathrm{~cm}$ had ovaries weighing up to $10 \mathrm{~g}$, whereas in individuals $>70.0 \mathrm{~cm}$ ovaries attained $\sim 40 \mathrm{~g}$. For this group, ovary weights showed a strong dispersion of points as a result of different developmental stages within the same length classes.

Diameter of nidamental glands varied from 0.1 to $0.6 \mathrm{~cm}$ in individuals $<70.0 \mathrm{~cm}$, and from 1.0 to $2.4 \mathrm{~cm}$ in individuals of $70.0-120.5 \mathrm{~cm}$ (Fig. $4 B$ ).

Liver weights varied from 10 to $100 \mathrm{~g}$ for individuals from birth up to $70.0 \mathrm{~cm}$, and from 30 to $280 \mathrm{~g}$ for individuals $>70.0 \mathrm{~cm}$ (Fig. $4 C$ ).

Ovarian follicles were divided into 'white' and 'vitellogenic' categories. Both juveniles and adults bear white follicles, but the number of specimens showing only white follicles decreases in larger class sizes. Vitellogenic follicles in the sample ranged from 0.3 to $1.8 \mathrm{~cm}$ in diameter. The smallest female showing vitellogenic follicles was $63.0 \mathrm{~cm}$, whereas pregnancy was not observed in any female smaller than $70.0 \mathrm{~cm}$.
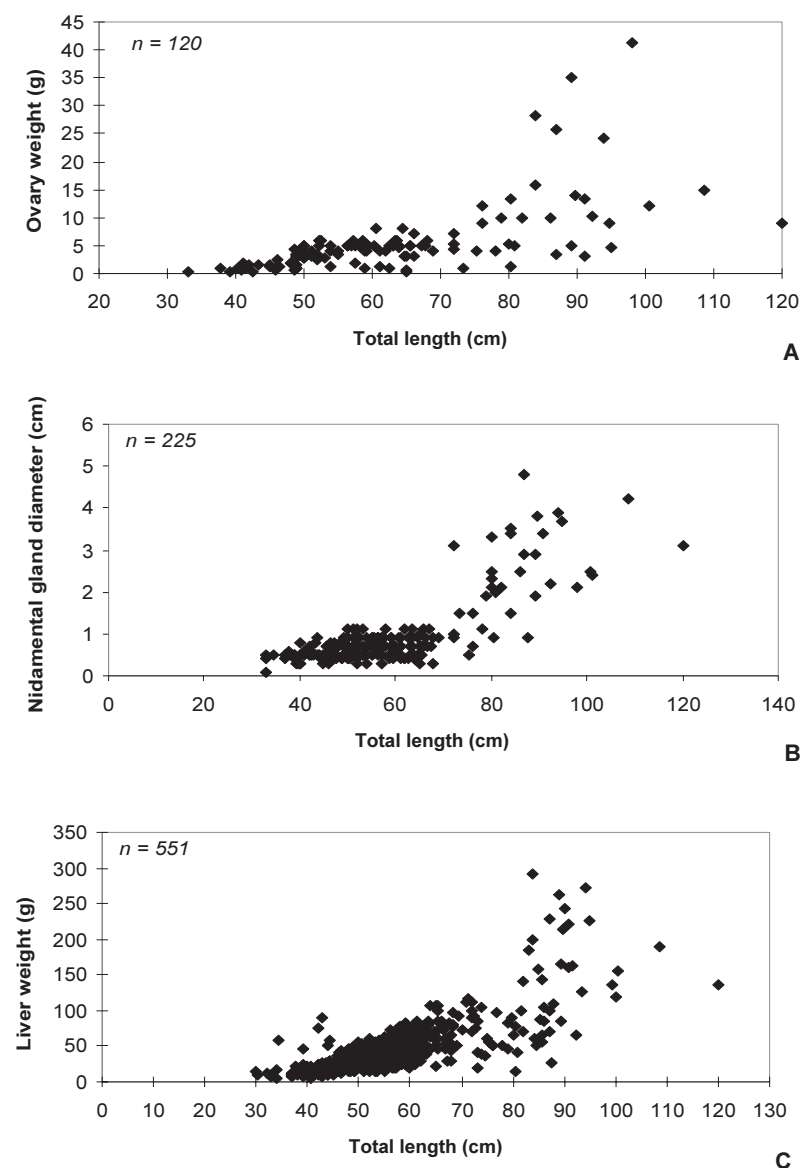

Fig. 4. Relationship between $(A)$ ovary weight and total length, $(B)$ nidamental gland diameter and total length, and $(C)$ liver weight and total length, for females of $C$. porosus from northern Brazil.
There was a significant relationship between the number of embryos/eggs and female size; the equation of the linear function is $\ln n_{\text {embryos }}=-25.473+5.977 \ln [\mathrm{TL}](n=15 ; r=0.86)$.

\section{Seasonal cycle}

Among 47 females $>70.0 \mathrm{~cm}$ (pregnant or not), there were no significant seasonal differences in mean length or in mean weight $(P>0.05)$ (Table 1). In contrast, significant differences were found in ovary weight throughout the year $(P<0.05)$. Thus, the ovary reached $>350 \mathrm{~g}$ in the third quarter, decreasing remarkably towards the first quarter when lowest values occurred. Liver weight also differed significantly $(P<0.05)$ throughout the period, with the highest and the lowest mean values found in the third and first quarters, respectively.

Follicle diameter and mean maximum width of the nidamental gland varied $(P<0.05)$ throughout the year, with the highest values found in the third quarter and lowest in the fourth quarter in both cases (Table 1).

The smallest vitellogenic follicles measured $0.3 \mathrm{~cm}$ diameter and the largest were $>1.5 \mathrm{~cm}$, which is considered as the ovulation size. Atretic vitellogenic follicles of $\sim 1.8 \mathrm{~cm}$ were present in haemorrhagic ovaries of recently fertilized females with uterine eggs $(n=2)$, whereas the six pregnant females carrying developed embryos (mean $28.5 \mathrm{~cm}$ ) had small vitellogenic follicles of around $0.5 \mathrm{~cm}$. Non-pregnant females of $70-100 \mathrm{~cm}(n=35)$ had vitellogenic follicles of $\sim 0.5 \mathrm{~cm}$; of these, specimens $<80.0 \mathrm{~cm}(n=23)$ were considered to be recently mature. Four non-pregnant females $(87.0 \mathrm{~cm}, 89.7 \mathrm{~cm}, 91.0 \mathrm{~cm}$ and $94.0 \mathrm{~cm})$ caught during August-September had vitellogenic eggs of $1.0-1.4 \mathrm{~cm}$, indicating imminent ovulation.

In 58 adult males, variations in testis weight and epididymis width varied significantly throughout the year, with lower mean values recorded in the fourth quarter $(P<0.05$; Table 2$)$.

\section{Discussion}

The largest specimen of $C$. porosus ever recorded was a $134.0 \mathrm{~cm}$ female, from Cananéia, Brazil, 2459'S (Sadowsky 1967), the largest recorded on the Maranhão Coast was a $128.5 \mathrm{~cm}$ female in November 1983 (Lessa, unpublished), and the largest collected during the present study was a 120.5 $\mathrm{cm}$ female. These records seem to confirm that, like many other elasmobranchs, females attain larger sizes than males despite the similar growth demonstrated for both sexes. This may be due to reduced growth in males after maturity or to a difference in mortality between the sexes (Natanson et al. 1995). The reasons for the differences in size between sexes, however, remain uncertain and additional studies are required (Lessa and Santana 1998).

The absence of a significant difference in gutted weight between the sexes is due to the preponderance of juveniles in the overall sample throughout the year, since juveniles are not subject to weight variations related to reproductive cycle. This high proportion of juveniles is in part attributed to the 
Table 1. Quarterly variations in measurements of $C$. porosus females off the Maranhão coast, northern Brazil TL, total length; GW, gutted weight; NGD, nidamental gland diameter; >ovum, largest ovarian follicle diameter; >embryo, largest embryo. Sample size in parenthesis

\begin{tabular}{|c|c|c|c|c|c|c|c|c|}
\hline Quarter & $\mathrm{TL}(\mathrm{cm})$ & GW (g) & Ovary (g) & Uteri (g) & NGD (cm) & $>$ ovum $(\mathrm{cm})$ & $>$ embryo $(\mathrm{cm})$ & Liver (g) \\
\hline 1 & $\begin{array}{c}86.4 \pm 12.9 \\
(19)\end{array}$ & $\begin{array}{c}3066 \pm 409 \\
(19)\end{array}$ & $\begin{array}{c}70.1 \pm 153 \\
(13)\end{array}$ & $\begin{array}{c}923.9 \pm 72 \\
\text { (3) }\end{array}$ & $\begin{array}{c}1.07 \pm 0.5 \\
(12)\end{array}$ & $\begin{array}{c}0.63 \pm 0.6 \\
\quad(7)\end{array}$ & $\begin{array}{l}31 \\
(2)\end{array}$ & $\begin{array}{c}74.21 \pm 42.2 \\
(14)\end{array}$ \\
\hline 2 & $\begin{array}{c}84.1 \pm 8.7 \\
\quad(12)\end{array}$ & $\begin{array}{c}3401 \pm 499 \\
(7)\end{array}$ & $\begin{array}{c}302.9 \pm 305 \\
(9)\end{array}$ & $\begin{array}{c}422 \pm 258.7 \\
\text { (3) }\end{array}$ & $\begin{array}{c}1.17 \pm 0.3 \\
(9)\end{array}$ & $\begin{array}{c}0.65 \pm 0.2 \\
(8)\end{array}$ & $\begin{array}{c}27.5 \pm 0.7 \\
\quad(2)\end{array}$ & $\begin{array}{c}116.63 \pm 40 \\
(12)\end{array}$ \\
\hline 3 & $\begin{array}{c}86.28 \pm 7.7 \\
\text { (9) }\end{array}$ & $\begin{array}{c}3700 \pm 124 \\
(8)\end{array}$ & $\begin{array}{c}362 \pm 124 \\
(7)\end{array}$ & & $\begin{array}{c}1.93 \pm 0.3 \\
(7)\end{array}$ & $\begin{array}{c}1.13 \pm 0.1 \\
(7)\end{array}$ & & $\begin{array}{c}170.4 \pm 74.8 \\
\text { (9) }\end{array}$ \\
\hline 4 & $\begin{array}{c}85.5 \pm 13.9 \\
(7)\end{array}$ & $\begin{array}{c}3750 \pm 714 \\
(7)\end{array}$ & $\begin{array}{c}233.9 \pm 8 \\
(8)\end{array}$ & $\begin{array}{c}1410 \\
(1)\end{array}$ & $\begin{array}{l}0.9 \pm 0.8 \\
\quad(6)\end{array}$ & $\begin{array}{c}0.45 \pm 0.1 \\
\quad(6)\end{array}$ & $\begin{array}{l}32 \\
(1)\end{array}$ & $\begin{array}{c}124.3 \pm 68.2 \\
(8)\end{array}$ \\
\hline
\end{tabular}

Table 2. Quarterly variations in measurements of $C$. porosus males off the Maranhão coast, northern Brazil TL, total length; GW, gutted weight; epidid, epididymis width. Sample size in parenthesis

\begin{tabular}{lcccccc}
\hline Quarter & TL $(\mathrm{cm})$ & GW $(\mathrm{g})$ & clasper $(\mathrm{cm})$ & epidid. $(\mathrm{cm})$ & testis $(\mathrm{g})$ & liver $(\mathrm{g})$ \\
\hline 1 & $83.6 \pm 7.7$ & $2860 \pm 224$ & $7.03 \pm 1.09$ & $1.21 \pm 0.34$ & $19.2 \pm 9.6$ & $72.6 \pm 30.3$ \\
& $(19)$ & $(17)$ & $(19)$ & $(19)$ & $(15)$ & $(16)$ \\
2 & $83.8 \pm 12.7$ & $2670 \pm 389$ & $7.64 \pm 0.69$ & $1.3 \pm 0.70$ & $16.2 \pm 12.37$ & $84.3 \pm 38.7$ \\
& $(7)$ & $(6)$ & $(7)$ & $(17)$ & $(4)$ & $(6)$ \\
3 & $81.4 \pm 7.1$ & $2834 \pm 185$ & $6.65 \pm 1.43$ & $1.27 \pm 0.29$ & $19.9 \pm 9.6$ & $106.3 \pm 64.1$ \\
4 & $(24)$ & $(24)$ & $(22)$ & $(20)$ & $(20)$ & $(23)$ \\
& $79.9 \pm 8.6$ & $2612 \pm 292$ & $7.16 \pm 0.65$ & $1.1 \pm 0.26$ & $9.3 \pm 11.2$ & $89.6 \pm 68.9$ \\
\hline
\end{tabular}

operation of fisheries directed towards the Serra-Spanish mackerel inside or near mouths of estuaries where juveniles of the smalltail shark concentrate.

In regard to the distribution pattern, the study area is part of a shallow (average depth $\sim 50 \mathrm{~m}$ ) and wide continental shelf, with the $100 \mathrm{~m}$ isobath from $105 \mathrm{~km}$ off Tubarão Bay to 220 $\mathrm{km}$ off the Gurupi River. Experimental fisheries for sharks, using gill-nets with stretched meshes $20-30 \mathrm{~cm}$, conducted in the study area, reached deeper waters along the outer part of shallow banks and islands along the external rim of bays (within the $30 \mathrm{~m}$ isobath), collecting only adults throughout the year (mean length $91.2 \mathrm{~cm}$ ) (Stride et al. 1992). The littoral distribution of the species, restricted to upper shelves (down to $36 \mathrm{~m}$, Compagno 1984), is in accordance with Compagno (1984) and Stride et al. (1992). Movements inside estuaries for parturition and mating and outside of bays towards protected areas of shallow banks are part of the cycle of the species on the Maranhão coast. These areas are shared with other common sharks that have identical distribution patterns, among them Isogomphodon oxyrhynchus and Sphyrna tudes (Stride et al. 1992; Lessa et al. 1999).

Referring to male sexual development, discontinuities were demonstrated in development of several organs at 71.0 $\mathrm{cm}$, corresponding to the size at maturity (Lessa 1986-87). These represent the point of inflection of a exponential curve where the organ development changes with the onset of maturity. In females, the onset of vitellogenesis occurs at $63.0 \mathrm{~cm}$, and pregnancy was, in this small sample, observed for the first time at $70.0 \mathrm{~cm}$. All organs considered for inferences on sexual development showed a discontinuity in growth when individuals reached $70.0 \mathrm{~cm}$. The onset of maturity at identical lengths in both sexes concurs with the similarity in growth of the species (Lessa and Santana 1998).

The high values for ovary weight, nidamental gland diameters, ovarian follicle diameter and liver weight in the third quarter suggest that ovulation takes place in this period. This implies the existence of a relatively defined cycle; the appearance in catches of the smallest free-living specimens in October-November support this. These records indicate a gestation period of about one year, not differing from Compagno (1984) who assumed 10 or more months as the gestation time.

Regarding litter sizes, Branstetter (1990) mentions 6 embryos; Compagno (1984) 2-7, and the maximum in the present study area was 9 embryos. The number of embryos increases with female size, as has been shown for many other species, such as Rhizoprionodon terreaenovae (Parsons 1983), Galeorhinus australis (Olsen 1984), Carcharhinus brevipinna, C. plumbeus, Rhizoprionodon taylori (Stevens and McLoughlin 1991) and Sphyrna tiburo (Lessa and Silva 
1992). Following Branstetter's criteria (1990), the species can be grouped with sharks producing few $(<15$, usually $6-8$ embryos) and large young that are $>20 \%$ of the maximum adult size at birth.

Observations on variation in follicle size throughout the year failed to show the occurrence of successive pregnancies without a resting break. C. porosus would be expected to accord with Branstetter's hypothetical strategy of no resting period between pregnancies, since the species is assumed to be similar to Rhizoprionodon spp. (Parsons 1983) and Sphyrna tiburo (Lessa and Silva 1992); however, the present study was based on a limited number of ovaries of pregnant females $(n=6)$ and this precludes further speculation.

Furthermore, according to Branstetter (1990), species inhabiting littoral areas are subject to high levels of natural mortality during the young stages, and this has to be compensated by fast growth, large litter size, dominance of females among adults, and reproductive cycles without resting periods. However, differing from the aforementioned postulates, a slow growth $(k<0.10$, Lessa and Santana 1998) and small litters have been found for $C$. porosus.

Although the number of reproductively active specimens in the present sample was not small overall, determination of the sex ratio was hampered by the reduced number of specimens in certain states of reproduction, such as pregnant females carrying small and medium-sized embryos. For this reason, additional sampling of adults throughout the year is required in order to provide further information on these features of the reproductive cycle.

In summary, fisheries affect mainly the juvenile part of the stock, and this may lead to growth-overfishing, because C. porosus presents a life strategy that includes slow growth, small litters and long gestation period, compatible with the $K$-selected pattern.

\section{Acknowledgments}

We thank the staff of LABOHIDRO/UFMA. This research was funded by Comissão Interministerial para os Recursos do Mar-SECIRM. A research grant was provided to the first author by Conselho Nacional de Desenvolvimento Científico e Tecnológico-CNPq (Proc:301048/83-OC).

\section{References}

Batista, V. S., and Silva, T. C. (1995). Age and growth of juveniles of junteiro shark Carcharhinus porosus in the coast of Maranhão, Brazil. Revista Brasileira Biologia 55 (Supl. 1), 25-32.

Bigelow, H. B., and Schroeder, W. C. (1948). Sharks. In 'Fishes of the Western North Atlantic, part I'. Memoirs of Sears Foundation for Marine Research I, 53-546.

Branstetter, S. (1990). Early life-history implications of selected carcharhinoids and lamnoid sharks of the Northwest Atlantic. In 'Elasmobranchs as Living Resources: Advances in the Biology, Ecology, Systematics, and the Status of the Fisheries'. (Eds H. L. Pratt Jr, S. H. Gruber and T. Taniuchi) pp. 17-28. NOAA Technical Report. NMFS Circular No. 90.
Browner, J. E., and Zar, J. H. (1984). Field and laboratory methods for general ecology. (W. C. Brown: Dubuque, Iowa.) 226 pp.

Compagno, L. J. V. (1984). 'FAO Species Catalogue, Vol. 4. Sharks of the World, an Annotated and Illustrated Catalogue of Shark Species Known to Date. Part 2; Carcharhiniformes.' FAO Fisheries Synopsis 125, 251-655.

Garrick, J. A. F. (1982). Sharks of the Genus Carcharhinus NOAA Technical Report. NMFS Circular No. 445. 194 pp.

Lessa, R. P. T. (1986). Levantamento faunístico dos elasmobrânquios (Pisces, Chondrichthyes) do litoral ocidental do Estado do Maranhão. Boletim do Laboratório de Hidrobiologia, Universidade Federal do Maranhão, São Luis No. 7, 27-42.

Lessa, R. P. T. (1986-1987). Contribuição ao conhecimento da biologia de Carcharhinus porosus Ranzani, 1839 (Pisces, Chondrichthyes) das reentrâncias maranhenses. Acta Amazonica 16/17, 73-86.

Lessa, R., and Almeida, Z. (1997). Analysis of stomach contents of the smalltail shark Carcharhinus porosus from northern Brazil. Cybium 21(2), 123-33.

Lessa, R., and Menni, R. C. (1994). The chondricthyan community off Maranhão (northeastern Brazil). In 'Proceedings of the 4th Indo-Pacific Fish Conference'. pp. 138-72. (Ichthyological Society of Thailand: Bangkok.)

Lessa, R., and Santana, F. M. (1998). Age determination and growth of the smalltail shark, Carcharhinus porosus, from northern Brazil. Marine and Freshwater Research 49, 705-11.

Lessa, R. P., and Silva, T. C. (1992). Fecundity and reproductive cycle of the bonnethead shark Sphyrna tiburo (Linnaeus, 1758) from northern Brazil. Revista Brasileira de Biologia 52(4), 533-45.

Lessa, R., Batista, V., and Almeida, Z. (1999). Occurrence and biology of the daggernose shark Isogomphodon oxyrhynchus (Chondrichthyes : Carcharhinidae) off the Maranhão Coast (Brazil). Bulletin of Marine Science, in press.

Natanson, L. J., Casey, J. G., and Kohler, N. E. (1995). Age and growth estimates for the dusky shark Carcharhinus obscurus in the western North Atlantic Ocean. Fishery Bulletin 93, 116-26.

Olsen, A. M. (1984). Synopsis of biological data on the school shark Galeorhinus australis (Macleay, 1881). FAO Fisheries Synopsis 139, $1-42$.

Parsons, G. R. (1983). The reproductive biology of the Atlantic sharpnose shark, Rhizoprionodon terraenovae (Richardson). Fisheries Bulletin 81, 61-73.

Sadowsky, V. (1967). Selachier aus dem Litoral von São Paulo, Brasilien. Beiträge zur Neotropischen Fauna 5, 71-88.

Siegel, S. (1981). Estatística não paramétrica para Ciencias do Comportamento. (McGraw-Hill do Brasil Ltda Ed.: São Paulo.) 350 pp.

Sparre, P., and Venema, S. (1997). Introdução à avaliação de mananciais de peixes tropicais. Parte 1. Manual. FAO Documento Técnico Sobre as Pescas. 306/1. Rev. 2. 404 pp.

Stevens, J. D., and McLoughlin, K. J. (1991). Distribution, size and sex composition, reproductive biology and diet of sharks from northern Australia. Australian Journal of Marine and Freshwater Research 42, 151-99.

Stride, R. K., Batista, V. S., and Raposo, L. A. B. (1992). Pesca experimental de tubarão com redes de emalhar no litoral maranhense. São Luis, ODA/FINEP/UFMA, Vol. III, 160 pp.

Zar, J. H. (1984). 'Biostatistical Analysis.' 3rd Edn. (Prentice-Hall: NJ.)

Manuscript received 8 September 1998; revised and accepted 17 March 1999 